\title{
Can Trade Help Overcome Economic Crisis? Implications for Northeast Asia Creating a Regional FTA between Korea, China and Japan and Mega FTAs such as RCEP and TPP1
}

\author{
S. -C. Park
}

Sang-Chul Park - Doctor, Professor at Graduate School of Knowledge Based Technology and Energy, Korea Polytechnic University; 2121, Jeongwang-Dong, Siheung-City, Gyeonggi-Do, 429-793, Korea; E-mail: scpark@kpu.ac.kr

\begin{abstract}
Since the 1990s, in terms of gross domestic product (GDP) and trade volume, the global economic and trade system has been dominated by the European Union (EU), the North American Free Trade Agreement (NAFTA) and Northeast Asia. However, the global financial crisis in 2008 created a new global economic order and governance structure consisting of both established global economic powers such as the members of the G7 and emerging economic powers such as the G20 and the BRICS grouping of Brazil, Russia, India, China and South Africa. Under changing global economic conditions, global trade has contributed to rapid economic growth in the last five decades. Among free trade agreements (FTAs), the EU has produced the most advanced regional economic integration. The EU's single market complicates the efforts of Northeast Asian countries to create regional bilateral and multilateral FTAs and participate in various mega FTAs such as the Regional Comprehensive Economic Partnership (RCEP) and the Trans-Pacific Partnership (TPP). As a result, their economic interests are deeply divided, and related to political and security issues in the Northeast Asian context. This makes it difficult for Northeast Asian countries to undertake economic integration along the lines of the EU. This paper examines the possibility of a regional FTA between Korea, China and Japan which could be a starting point for formal regional economic integration, creating a reliable platform to strengthen their trade and further economic growth. This paper also considers the interest each of these three nations has in participation in mega FTAs such as the RCEP and TPP. Finally, it analyzes the best scenario for each country with respect to participation in multilateral FTA and mega FTAs.
\end{abstract}

Key words: single market; regional economic integration; FTA, mega FTA; economic growth, FTA strategy

For citation: Park S.-C. (2017) Can Trade Help Overcome Economic Crisis? Implications for Northeast Asia Creating Regional FTA between Korea, China, and Japan and Mega FTAs such as RCEP and TPP. International Organisations Research Journal, vol. 12, no 2, pp. 104-128 (in Russian and English). DOI: 10.17323/1996-7845-2017-02-104

${ }^{1}$ The editorial board received the article in November 2016.

This work was supported by the National Research Foundation of Korean government [NRF 2015S1A3A2046684]. 


\section{Introduction}

Since the 1990s, in terms of gross domestic product (GDP) and trade volume, the global economic and trade system has been dominated by the European Union (EU), the North American Free Trade Agreement (NAFTA) and Northeast Asia. However, the global financial crisis in 2008 created a new global economic order and governance structure consisting of both established global economic powers such as the members of the G7 and emerging economic powers such as the G20 and the BRICS grouping of Brazil, Russia, India, China and South Africa. Additionally, China has tried to build a new form of cooperative platform in world politics and global economy by creating G2 in 2013 [Dicken, 2015; Kirton, 2013; Looney, 2014].

Global trade has contributed to rapid economic growth in the world last five decades. However, the growth in global trade has slowed since the global financial crisis. In 2016, growth in the volume of world trade is expected to remain at $2.8 \%$, unchanged from the $2.8 \%$ increase registered in 2015 . Imports by developed countries will be moderate this year, while demand for imported goods in developing Asian economies could rise. However, despite rising imports in Asia, the ratio of trade growth in the world has been lower than the ratio of global economic growth since 2013.For this reason, many countries have tried to create bilateral, multilateral, regional and mega free trade agreements (FTAs) in order to boost their trade volumes and economic growth [WTO, 2016; IMF, 2015].

Among FTAs, the European Union (EU) has experienced the most advanced regional economic integration. There is no doubt that the European single market is the core of Europe's economic integration architecture. The EU adopted the Single European Act (SEA) in 1986 clearing the way for the creation of the single market guaranteeing the free movement of people, goods, services and capital in the European Economic Area. Since the EU was launched in 1993, it has been continuously modified to keep pace with more recent developments, particularly the growing importance of the service sector. After more than 20 years, the general consensus on the single market is that it has generated substantial positive economic growth effects. However, it is also true that the single market has not met the target predicted by the Ceccini Report in 1988 [European Commission, 2012a; Vetter, 2013].

Additionally, following the global financial crisis of 2008 that caused the Euro crisis, the EU experienced a sovereign debt crisis in 2010.Thus, more than 20 years after the SEA was signed, the single market is under threat. However, despite growing instability in the EU the European single market has been a model for East Asian economic integration, which has increased rapidly since the 1990s. The Asian financial crisis (AFC) in 1997 led to the creation of the Chiang Mai Initiative (CMI) in 1998 to serve as framework for economic and financial cooperation. Since then, East Asian economic integration has been intensified by regional trade and foreign direct investment (FDI). Interestingly, this integration has increased without institutions or legal 
frameworks other than that provided by the Association of Southeast Asian Nations (ASEAN) [Godement, 2013].

There are two important economic integration processes unfolding in East Asia. The first is the growth of ASEAN-led regionalism and the creation of a single market in 2015. The other is the institutionalization of FTA negotiations between Korea, China and Japan which began in November 2012 and are still an ongoing. Recent negotiations on ASEAN +6 and trilateral cooperation among Korea, China and Japan represent new efforts in pursuit of East Asian economic integration [Szczudlik-Tatar, 2013].

Rapidly intensifying economic integration in East Asia could impact the global economic order substantially. An ASEAN+6 FTA would create a market of more than 3 billion people with a GDP of about $\$ 17$ trillion, accounting for $40 \%$ of world trade in 2013. A trilateral FTA between Korea, China and Japan would create a market of more than 1.5 billion people, with a GDP of $\$ 14$ trillion, accounting for $35 \%$ of world trade in the same year [Hibert and Hanlon, 2013; Song, 2013].

The proposed ASEAN+6 FTA is a mega FTA referred to as the Regional Comprehensive Economic Partnership (RCEP) for which negotiations began in May 2013. The RCEP is regarded as a counterbalance to the Trans-Pacific Partnership agreement (TPP), which is a component of the U.S. pivot policy towards the Asia Pacific region, signed by 12 members in November 2015. By maneuvering between the Chinaled RCEP and the U.S.-led TPP, East Asian nations may be able to secure their national interests and find a balance between the two superpowers in the region. Under these circumstances, members in the region can seek maximum advantages through participation in both mega FTAs. However, the Trump administration decided on the withdrawal from TPP in January 2017 so that the China-led RCEP can be replaced as the only mega FTA in the Asia Pacific region that pursues free trade instead of protectionism.

This paper focuses on East Asian economic integration through FTAs in general and discusses how the European model can be applied in the Northeast Asian context in particular. At the same time, it analyzes why trade matters for economic growth in East Asia and how the mega FTAs can affect the trilateral FTA between Korea, China and Japan. Last, it explores ways to support Northeast Asian economic integration.

\section{Theoretical Debates}

The East Asian approach to economic integration differs from the European model. East Asian regionalism has not been driven by internal factors, but rather by external ones. It can be characterized as informal economic cooperation that is consensus based and not legally binding. There is considerable reluctance to engage in political integration or multilateral security cooperation. Even ASEAN, the only formalized institution in East Asia, privileges national interest, state sovereignty and equality between the members. 
In terms of regional economic integration, the EU adopted Balasa's approach, which is composed of five steps moving from free trade agreements, to a tariff union, a common market, economic and eventually political union. At present, the EU is in the fourth stage and heading for political union in the future although many challenges remain.

Compared with Europe, East Asia remains under institutionalized, not with standing ASEAN. That said, the drive to increase regional institutionalization is not new. Contrary to the European approach of focusing on a single institution, a number of regional institutions have emerged in East Asia to deal effectively with various regional issues and multiple institutions without systemic linkages may continue to increase in the region. Explanations of East Asian institutions point out that they have evolved in decentralized, contradictory and ad hoc ways instead of deepening and solidifying regionalism as was the case in Europe. Thus, regionalism in East Asia may be described according to some theoretical approaches to the issue as soft or informal regionalism [Pempel, 2010; Zhao, 1998; Katzenstein, 1997].

At the same time, it is also possible that East Asian regionalism will become more institutionalized in the coming decades as East Asian countries turn to bilateral FTAs and institutional engagement. In fact, bilateral FTAs completed in the 2000s have created a lattice of regionalism in East Asia that may ultimately transform bilateral relationships into plurilateral ones and establish a regional path toward institutionalization. Over time, several bilateral FTAs may become region-wide even without any regional centre due to the inevitably high transaction costs of interlocking and overlapping FTAs [Dent, 2003].

In fact, East Asian countries have joined multiple institutions whose memberships overlap with each other because they were not able to develop a core regional institution as the basis for regional economic and political integration and cooperation. Moreover, regional institutions in East Asia have developed in single issue areas without creating systematic linkages. As a result, there is no regional institution that deals with economics, politics or security comprehensively [Katzenstein, 2005; Pempel, 2013].

Accordingly, a theoretical perspective that envisions a plurilateral path toward regional institutionalization in East Asia is adopted in this paper to explain East Asian economic integration processes. This is because plurilateral theory can explain the East Asian dynamic economic development more comprehensively than theories of soft regionalism or informal regionalism.

\section{EU Single Market and Euro Crisis}

\section{Benefits of the EU Single Market}

There is no doubt that the single market has generated enormous benefits for EU members in many areas. From an economic point of view, it created various opportunities for total utility. First, it reduced direct costs owing to the abolition of border 
formalities and national regulations. Second, it enlarged economies of scale and created high sales potentials for companies able to access a bigger market. Third, harsh competition due to lower barriers to entry emerged. Fourth, labour force movements increased due to border mobility. Finally, lower financial transaction costs were realized because the liberalization of capital flows and greater financial integration made cross border financial transactions easier and less expensive [Vetter, 2013].

However, the benefits derived from the single market vary by degrees and the overall impact is quite mixed, producing unequal and different benefits across members. There are several reasons for this outcome.

First, intra-EU trade intensity varies from member to member. Intra-EU exports have reached over half of total exports in nearly every member state and in some states such as the Netherlands and Spain the share of intra-EU exports exceeds 70\%, although their shares started to decline after the global financial crisis in 2008 and the EU sovereignty debt crisis in 2011 (See Fig. 1).

Second, industrial competitiveness, based both on price components such as unit labour costs and non-price components such as innovative strength and technological advantage, plays a key role.

Third, economic structures generate more advantages in some members than in others. Specialized industries with rising economies of scale benefit from the single market because of the greater potential for efficiency gains.

Fourth, company size is also an important factor because bigger companies are on average more export oriented and therefore may realize more benefits from trade liberalization. Additionally, larger companies are better placed to establish international production networks across the EU and may thus enjoy more benefits than smaller firms.

Finally, the degree of liberalization in different states must be considered. Logically, consumers in previously highly protectionist members may benefit more from liberalization than consumers in states which were already relatively liberalized.

The benefits of the single market contributed to the growth of trade, investment flows and new employment. Intra-EU trade in goods increased from €800 billion in 1992 when the single market was created to $€ 2,800$ billion in 2011 - an increase from $12 \%$ of the EU's GDP in 1992 to $22 \%$ in 2011. It is noteworthy that EU members have gained greater leverage by implementing a common trade policy. After creating the single market, the EU was able to open markets and thereby boost trade and employment. Furthermore, the single market strengthened EU companies. EU exports to non-EU countries increased from $€ 500$ billion in 1992 to $€ 1,500$ billion in 2011, representing an increase from 8\% of the EU's GDP in 1992 to $12 \%$ in 2011. Along with intra-EU trade, the flow of FDI between EU members has increased rapidly, from $€ 64$ billion in 1992 to $€ 260$ billion in 2010 . It peaked in 2000 with over $€ 800$ billion and reached $€ 730$ billion before the economic downturn in 2007. FDI flows outside the EU also fell from $€ 560$ billion in 2007 to $€ 140$ billion in 2011 [EU Commission, 2012a]. 


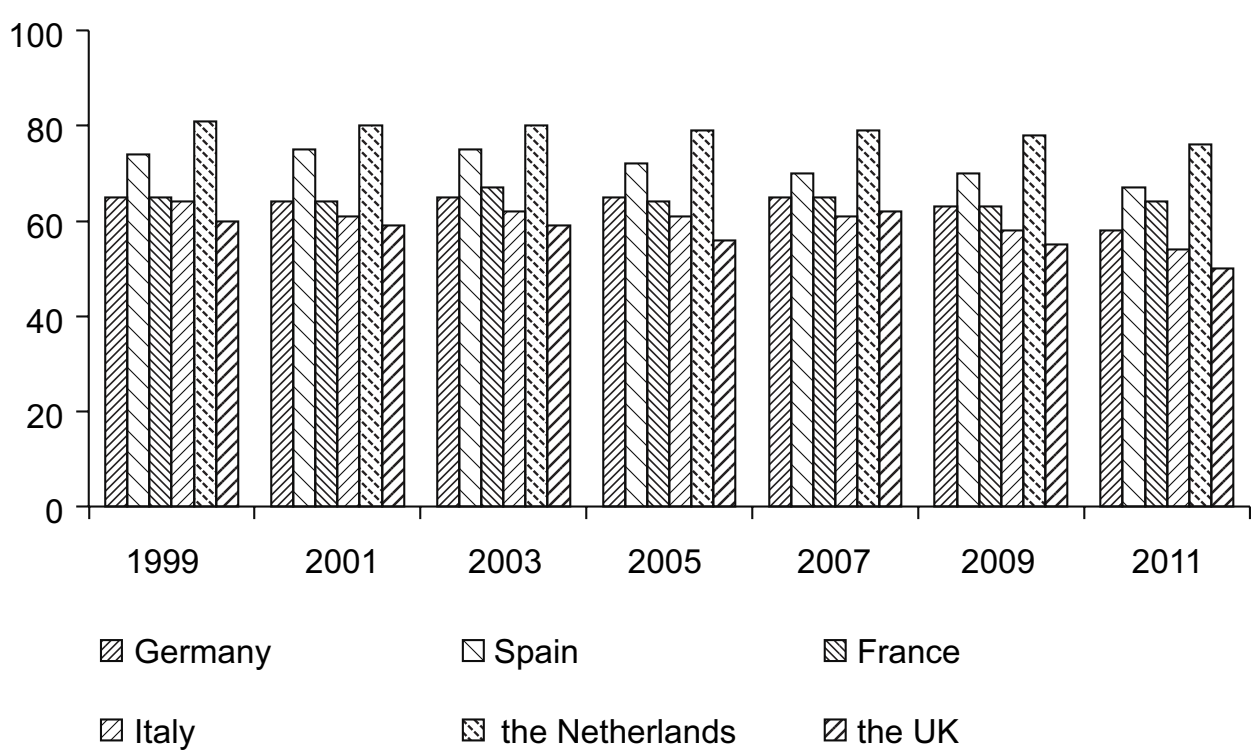

Fig. 1: Intra-EU Exports as a Share of Total Exports in the Major Member Nations (as of 19992011, \%)

Source: Eurostat, EU Statistics (2013).

\section{Costs of the EU Single Market}

Costs associated with the single market were generated by overregulation, inefficient bureaucracy and deficient allocation of tasks between the administrative levels of the federal system in the EU which created direct costs for companies. Additionally, opening national markets led to adjustment costs for members having less competitive companies than their foreign rivals. Standardized regulations in the single market have simplified many national administrative matters and made them unnecessary. Certainly, the single market causes additional bureaucratic and regulatory costs. However, it depends on how efficiently the national administrative systems operate and how they adapt to the transfer of the competences.

It was estimated in the mid-2000s that the total administrative costs for companies in the single market were equivalent to approximately $3.5 \%$ of EU output with major differences among members. The share of members with efficient regulations, such as Denmark, Finland, the UK and Sweden, was less than $2 \%$ of their output, while it accounted for over $4 \%$ in most of the southern and eastern European members. The less competitive members and regions were supported by the EU Cohesion Fund to mitigate the negative effects of liberalization in the single market. However, most empirical studies concluded that it did not generate significant growth stimulus [Kox, 2005; Vetter, 2013] (See Table 1). 
Table 1: Administrative Costs by Member in Share of GDP (as of 2005, \%)

\begin{tabular}{|c|c|c|c|c|c|c|c|c|c|c|}
\hline $\mathrm{AT}$ & $\mathrm{BL}^{*}$ & $\mathrm{CZ}$ & $\mathrm{DE}$ & $\mathrm{DK}$ & $\mathrm{ES}$ & $\mathrm{FI}$ & FR & UK & GR & HU \\
\hline 4.6 & 2.8 & 3.3 & 3.7 & 1.9 & 4.6 & 1.5 & 3.7 & 1.5 & 6.8 & 6.8 \\
\hline IE & IT & NL & PL & PT & $\mathbf{R E}^{* *}$ & SK & SI & SE & EU & \\
\hline 2.4 & 4.6 & 3.7 & 5.0 & 4.6 & 6.8 & 4.6 & 4.1 & 1.5 & 3.5 & \\
\hline
\end{tabular}

Source: [Kox, 2005].

Note: * BL combines Belgium and Luxembourg; ** RE combines the Baltic members, Malta and Cyprus.

Besides administrative costs in the EU, additional costs are generated by the market power of local incumbents, local regulations, missed links in the EU infrastructure, subsidies, language and local barriers and significant asymmetries of information between market players. Due to these costs, a majority of companies in the EU is not able to participate actively in the internal market. This shows that integration of the single market is still considered to be below standard [Mayor and Ottaviano, 2007; Pelkmans, 2012].

Based on cost-benefit analysis, empirical evidence shows that the effect of the single market on GDP is rather moderate compared with estimates made in the Ceccini Report. A comprehensive report based on the period 1958-2005 prepared by Straathof, Linders, Lejour et al. estimated that European integration boosted GDP in the EU by $2-3 \%$. The European Commission Report prepared by Ilkovitz, Dierr, Kovacs et al. also determined that the single market generated additional GDP growth of 2.2\% between 1992 and 2006. A more recent report carried out by the European Commission in 2012covering the years of the global financial crisis and sovereignty debt crisis arrived at a similar figure, finding additional GDP growth of 2.13\%. Copenhagen Economics estimated in 2012 that the single market measures in taxes, services, public procurement and mutual recognition might have created additional $2.4 \%$ of GDP, but one third of this did not materialize owing to substandard implementation [Straathof, Linders, Lejour et al., 2008; Ilkovitz, Dierr, Kovacs et al., 2007; EU Commission, 2012a; Copenhagen Economics, 2012].

The euro crisis caused by the sovereignty debt crisis made possible a break-up of the single currency that would lead to macroeconomic disruptions not only in the single market, but also in the rest of the global market. The euro crisis has generated negative views about EU integration not only in the EU, but also in other parts of the world. East Asian countries have admired the peaceful integration of Europe and had taken the EU's integration experience as a model for their own common future. However, the euro crisis changed East Asia's views on the EU integration processes - if cracks in the single market appear, East Asia's interests in modeling the EU will be limited. 


\section{Northeast Asian Economic Cooperation}

\section{Background}

China became the second largest economy in the world in 2010, and dominates in Northeast Asia. China’s GDP in 2015 accounted for $¥ 67.67$ trillion (USD 10.86 trillion), two times more than Japan's GDP and nearly eight times more than South Korea's in the same year. In light of Chinese economic power, economic cooperation in East Asia in general and Northeast Asia in particular has intensified. China has replaced Japan as the leader of the region and the economic dependence of East Asian countries on China has increased rapidly since the global financial crisis [China NBS, 2016; ADB, 2014].

Economic integration in East Asia has increased although an institution equivalent to the European single market has not emerged. Northeast Asian countries such as Korea, China and Japan have competed with one another in local, regional and global markets but have also cooperated with one another as evidenced by the bilateral FTA between Korea and China completed in 2015 and by the ongoing negotiation of a trilateral FTA since 2013.

\section{Bilateral FTA between Korea and China as well as Korea and Japan}

The FTA signed by Korea and China in 2015 governs nearly $\$ 300$ billion in trade. It is the largest FTA in trade terms among the major FTAs that Korea has signed since the turn of the century. However, the Korea-China FTA (China-Korea FTA) is viewed somewhat critically in terms of its impact on liberalization and the obligations it creates for trade and investment policies. Not only do the parties have twenty years to liberalize much of the trade between them, they also incorporated extensive exceptions to basic tariff reforms, and have deferred negotiations about market access for services and investment by several years (to begin later in this decade). As a result, business leaders and trade experts are not satisfied with the outcome of China-Korea FTA [Schott, Jung and Cimino-Isaacs, 2015].

The China-Korea FTA is a result of strategic trade policy for both parties. In 2000, the U.S. was Korea's top trade partner followed by Japan and the EU. However, China became Korea's top trade partner in 2004. From 2000 to 2014, Korea's global trade increased from $\$ 333$ billion to $\$ 1.1$ trillion while trade between Korea and China increased from $\$ 31.2$ billion to $\$ 235.4$ billion during the same period. As a result, China's share of Korean trade in goods rose from 9 to $21 \%$. China became the top source of Korean imports and exports of goods. Despite this rapid increase in the volume of bilateral trade, China's share of Korea's global trade has been stagnant for last eight years. Therefore, it was in Korea's interest to pursue the China-Korea FTA to regain the momentum of a decade ago (Fig. 2). 


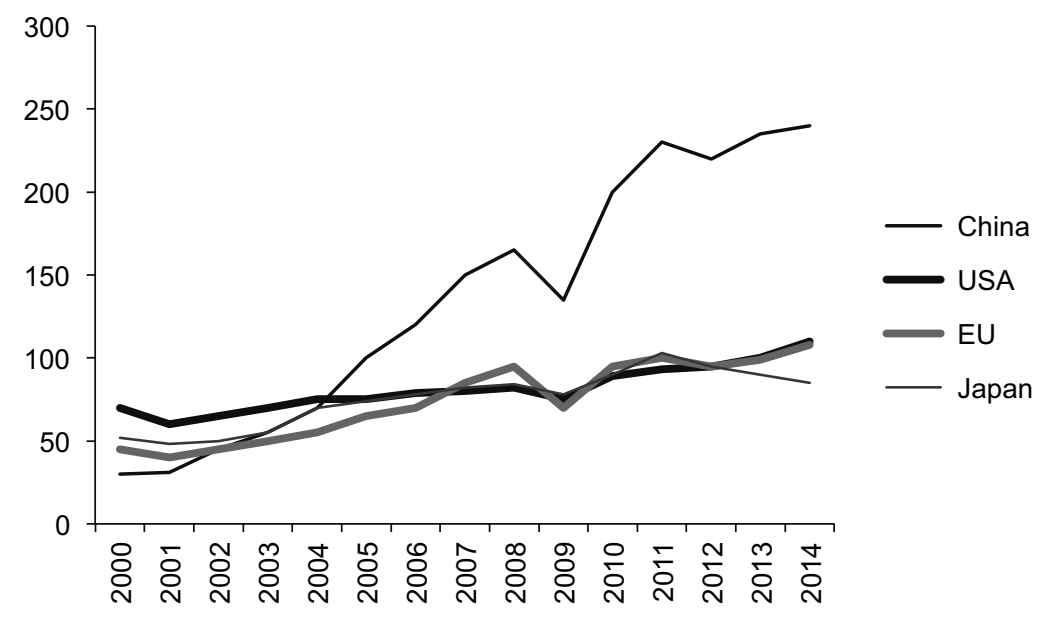

Fig. 2: Korea’s Trade in Goods with Major Trade Partners (as of 2000-2014, \$ billions)

Source: UN Comtrade via World Bank, World Integrated Trade Solutions (WITS) database, 2001-2015.

While trade in services between Korea and China is rather small it has grown rapidly over the past two decades, increasing from $\$ 4.6$ billion in 2000 to $\$ 34.1$ billion in 2014 - an average of $17 \%$ growth per year. China's share of Korean services exports rose from $7 \%$ to $16 \%$ in the same period. In trade of services, the U.S. has remained the top trade partner for Korea with a $21 \%$ share of Korea's total services trade. However, Korean exports of services to China grew an average of $21 \%$ per year, compared to an average increase of only 5\% per year to the U.S. between 2000-2014 (Fig. 3).

FDI is one of the most important components for expansion of bilateral trade. FDI in both countries remains largely in manufacturing and is limited in the service industries. The stock of FDI in Korea increased nearly two times from $\$ 514$ billion in 2005 to $\$ 998$ billion in 2014. China's share rose more than three times from $1.4 \%$ to $4.4 \%$ during the same period. Korean outward FDI increased more than four times from $\$ 160$ billion in 2005 to $\$ 717$ billion in 2014, while Korean FDI in China rose almost sevenfold from $\$ 20$ billion to $\$ 132$ billion in the past decade. Most FDI in China is channeled into the automobile and information technology sectors. Recently, it is also being targeted toward consumer goods in order to meet growing domestic demand and the policy shift of the Chinese government [KITA, 2014] (Table 2).

Investment liberalization in China is the highest priority for Korea in the ChinaKorea FTA because outward FDI to China has increased rapidly in recent years. At the same time, Korea sees opportunities in the Chinese market for Korean service industries. In fact, the quality of Chinese FTA provisions in investment has improved incrementally after China signed the investment chapter of the China-New Zealand FTA in 2008, widely acknowledged to have upgraded the Chinese commitment to liberalization. Since then, China's path to liberalization has been further entrenched by the 2012 
China-Canada Bilateral Investment Treaty (BIT) and the Korea - China - Japan BIT which came into force in 2014 [Schott and Cimino, 2015].

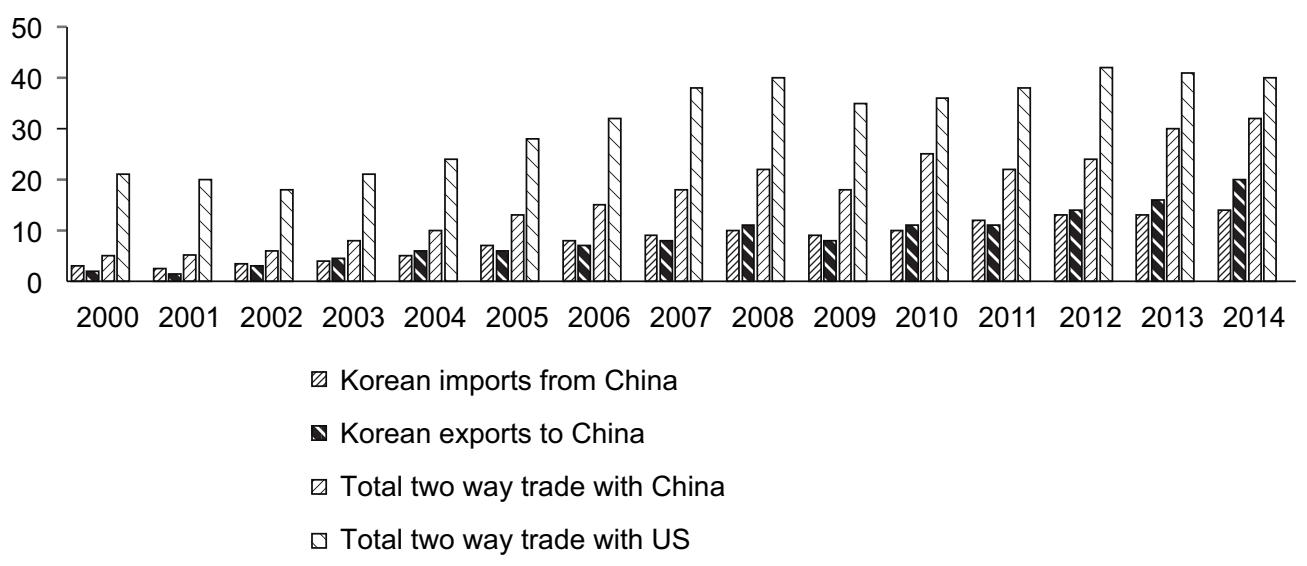

Fig. 3: Korean Services Trade with China and the U.S. (as of 2000-2014)

Source: Bank of Korea, Economic Statistics System, 2001-2015

Table 2

\begin{tabular}{|c|c|c|c|c|c|c|}
\hline \multirow{2}{*}{ Year } & \multicolumn{3}{|c|}{$\begin{array}{c}\text { Korean Outward Foreign Direct } \\
\text { Investment Stock }\end{array}$} & \multicolumn{3}{c|}{$\begin{array}{c}\text { Korean Inward Foreign Direct } \\
\text { Investment Stock }\end{array}$} \\
\cline { 2 - 7 } & World & China & & World & China & \\
\cline { 2 - 7 } & Billion USD & $\begin{array}{c}\text { Billion } \\
\text { USD }\end{array}$ & \% of total FDI abroad & Billion USD & $\begin{array}{c}\text { Billion } \\
\text { USD }\end{array}$ & $\begin{array}{c}\text { \% of total FDI } \\
\text { abroad }\end{array}$ \\
\hline 2005 & 160 & 20 & 12,3 & 514 & 7 & 1,4 \\
\hline 2006 & 228 & 26 & 11,3 & 622 & 11 & 1,8 \\
\hline 2007 & 333 & 58 & 17,3 & 782 & 14 & 1,8 \\
\hline 2008 & 336 & 46 & 13,6 & 607 & 6 & 1 \\
\hline 2009 & 360 & 56 & 15,5 & 730 & 10 & 1,3 \\
\hline 2010 & 406 & 64 & 15,8 & 828 & 18 & 2,1 \\
\hline 2011 & 453 & 74 & 16,3 & 841 & 23 & 2,7 \\
\hline 2012 & 534 & 80 & 14,9 & 955 & 29 & 3,1 \\
\hline 2013 & 621 & 109 & 17,5 & 1005 & 36 & 3,6 \\
\hline 2014 & 727 & 132 & 18,5 & 998 & 44 & 4,4 \\
\hline
\end{tabular}

Source: Bank of Korea, Economic Statistics System, 2006-2015.

Investment negotiations between China and Korea on market access will continue for two years beyond the FTA's coming into effect in December 2015. This delay may 
contribute to the efficient functioning of the China-Korea FTA, and may work in Korea's favour as China faces pressure from the U.S. to open further sectors to FDI as a part of the ongoing China-U.S. BIT negotiations. The China-Korea FTA has improved the investment provisions in terms of scope and coverage as well as the minimum standard of treatment when compared to the Korea-China BIT and the China Korea - Japan BIT.

The negotiation of a FTA between Korea and Japan started in December 2003 and is still in progress. However, negotiations were stopped after the sixth meeting in 2004 as a result of disagreement over the opening up of agricultural and industrial sectors, and lingering political and historical issues remain. Korea and Japan share some common characteristics in their patterns of trade and industrial structures. However, although Japan is one of its major trading partners, Korea is reluctant to discuss the FTA with Japan due to its automobile industry. For its part, Japan is afraid of opening its agricultural sector [Hong and Oh, 2013].

\section{Trilateral FTA between Korea, China and Japan}

Many countries were interested in regional trade agreements in the 1990s due to slow progress in market liberalization under World Trade Organization (WTO) oriented multilateralism. In this context, the global trend towards bilateral FTAs has had a significant impact on the trade policy of Northeast Asian countries. Korea, China and Japan joined this trend in the late-1990s and concluded bilateral FTAs mainly targeting trade partners in Asia. Furthermore, they started to engage in the formation of mega FTAs such as RCEP and TPP after 2010 [Yoshimatsu, 2014].

These three states have a high level of trade interdependence in their economic and industrial structures. Therefore, the formation of the trilateral FTA could be expected to generate substantial economic benefits for all parties. Representative research institutes of the three countries commenced a joint study of the trilateral FTA in 2003. A formal joint study began in 2010 and led to the launching of formal negotiations in 2012. The trilateral FTA is still being negotiated.

The trilateral FTA would have a tremendous impact on regional trade, economic growth and industrial structure in the three states in particular and on global trade and economic growth in general. At the same time, it would create feasible paths for free trade areas in Northeast Asia. Bi- or trilateral FTAs among the three nations could be a good starting point from which to build a regional economic mindset and system [Jin, Koo and Sul, 2006; Kimura and Ando, 2008; Choi, 2013; Madhur, 2013].

The trilateral economic bloc is the most important part of the Asian economy. The three states are among top G20 members. Therefore, any potential changes or instability in the region may cause severe impacts both regionally and globally. GDP in the three state will reach $\$ 23$ trillion in 2019, ahead of both the U.S. and the EU. Furthermore, its contribution to the world GDP will also be the highest at $23 \%$ in the same year [IMF, 2014] (Fig. 4 and 5). 


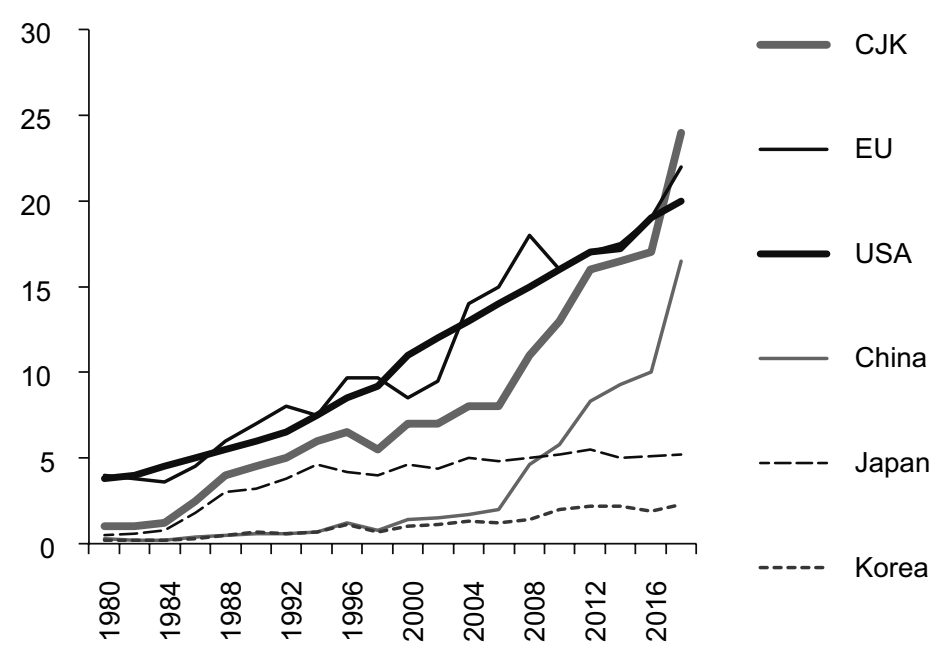

Fig. 4: Trends of GDP in the World Major Economies, Current Prices (\$ Trillion)

Source: International Monetary Fund (2014). World Economic Outlook Database, October. Washington DC: IMF.

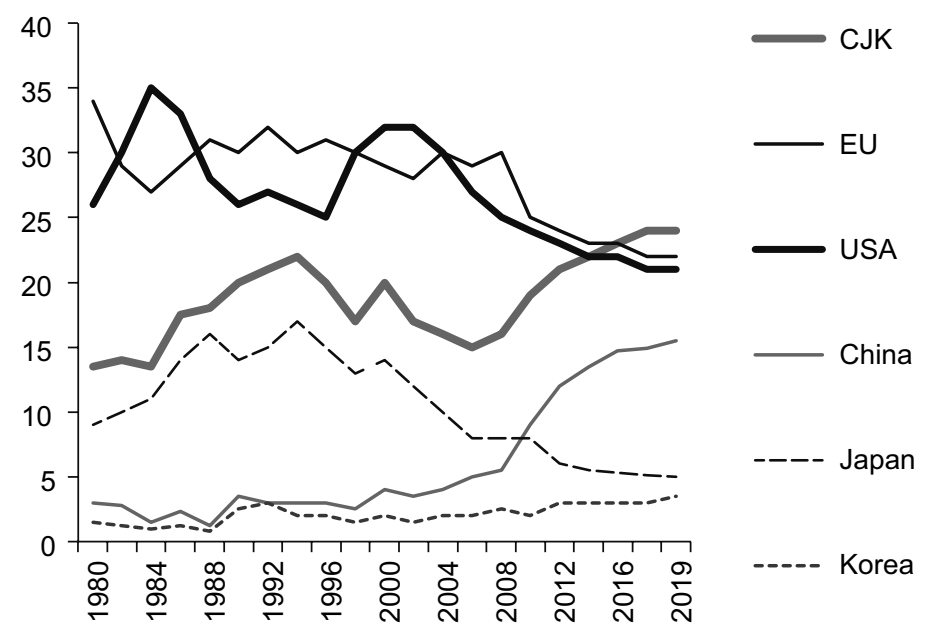

Fig. 5: Contribution to World GDP Based on Current Prices (as of 1980-2019, \%)

Source: International Monetary Fund (2014). World Economic Outlook Database, October. Washington DC: IMF.

The formation of the trilateral FTA has been accompanied not only by economic calculation, but also by political calculation given that the three states have been long-time rivals with historical and territorial conflicts. Furthermore, the economic and trade conditions in the Asia-Pacific region have been extremely complex after the creation of various FTA initiatives with overlapped and nested institutional structures. 
Under such conditions, it is natural that three states commit to the trilateral FTA with a strategic approach at the systemic level [Chiang, 2013; Corning, 2014].

It is important to examine the potential for intraregional trade between Korea, China and Japan the last two decades. Overall, the share of intraregional trade between the three states as a percentage of their total trade increased from $12.3 \%$ to $19.1 \%$ in 2014. It increased to $24.1 \%$ in 2004 and declined to $19.1 \%$ since then. Intraregional trade between the three states has been strengthened over the last two decades. However, it is much lower than in other trade blocs such as ASEAN, the EU and NAFTA in the same period [IMF, 2015] (Fig. 6).

The share of intraregional trade as a percentage of total trade is a good point of comparison with other regional trade blocs. However, it could misrepresent the degree of economic integration because a larger bloc could exhibit a higher share of intraregional trade due to its market size. Therefore, it is necessary to examine the intraregional trade intensity, which offers a deeper analysis than the share of intraregional trade. The intraregional trade intensity index can be calculated by the intraregional share adjusted by the region's share in the world trade. It can be determined that the region has a bias toward trading with itself if the indicator is bigger than 1 [Lee, 2015].

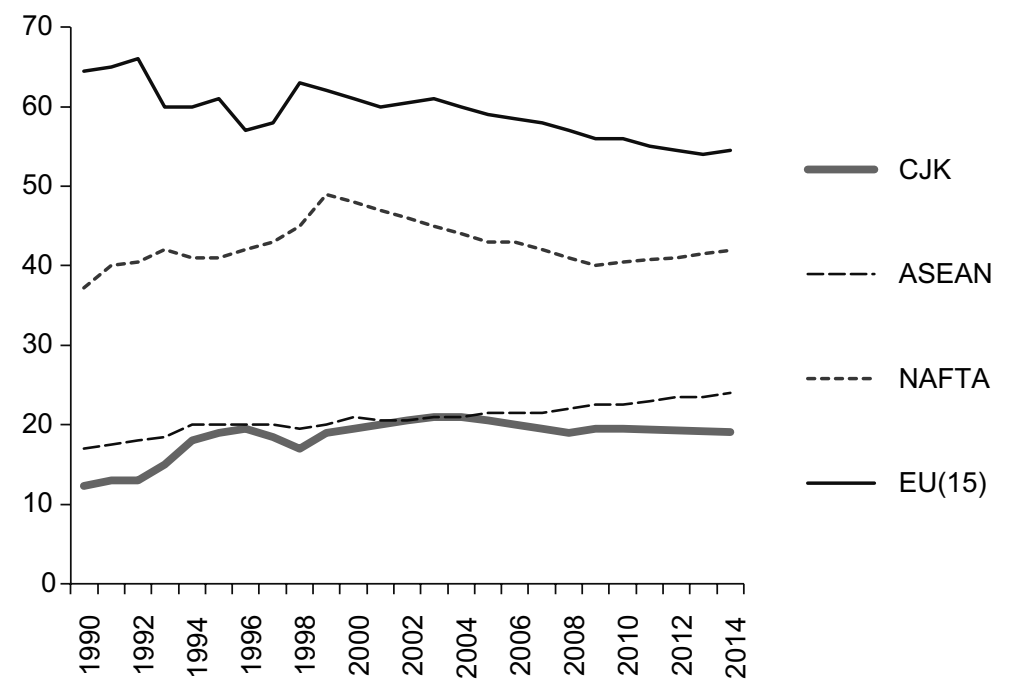

Fig. 6: Comparison of Intraregional Trade in Major Trade Blocs (\%)

Source: International Monetary Fund (2015) Direction of Trade Statistics. Washington DC: IMF.

Based on this index, intraregional trade intensity between Korea, China and Japan increased from 1.08 in 1990 to 1.74 in 2003 and declined to 1.03 in 2014. It means that while the intraregional trade pattern intensified until 2003, it has declined since then. There is almost no bias toward trading among the three states in 2014. In fact, it is lower than in 1990. Additionally, intraregional trade intensity of the three states has 
been much lower than in ASEAN, the EU and the NAFTA during the same period. Exceptionally, it was slightly higher than in the EU only between 2001 and 2004 [IMF, 2015] (Fig. 7).

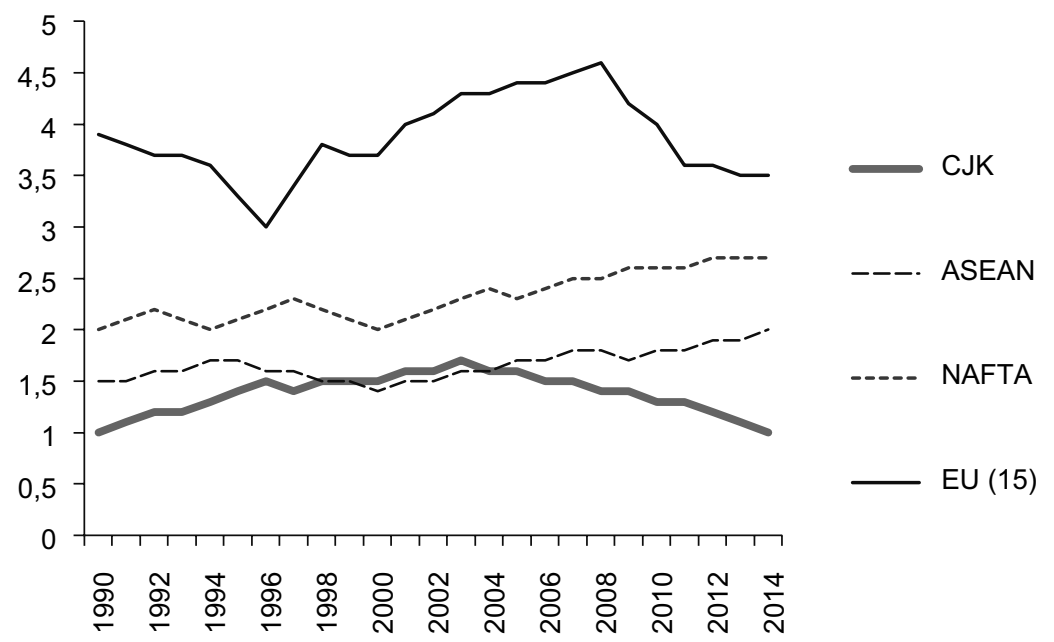

Fig. 7: Comparison of Intraregional Trade Intensity in Major Trade Blocs

Source: International Monetary Fund (2015) Direction of Trade Statistics. Washington DC: IMF.

The first round of Korea - China - Japan FTA negotiations began in Seoul in 2013. Since then, eight rounds have taken place up to 2015. These negotiations involve working level meetings and Chief Delegate level meetings. Since the launch of negotiations in 2013, there has been limited progress, but no consensus on modalities regarding trade in goods. However, the three parties have agreed to adopt a negative approach in investment and have made some progress in intellectual property rights (IPR), competition policy, rules of origin (ROO) and other issues [Lee, 2015].

The slow progress of the trilateral FTA negotiations is due mainly to the lack of leadership and weakened momentum for the agreement - Korea and China have concentrated on their bilateral FTA negotiations while Japan has focused on the TTP negotiations. The two negotiations were completed in 2015 while trilateral FTA negotiations were ongoing. Moreover, it is noteworthy that political relations between Korea and Japan and between China and Japan have significantly worsened since the launch of trilateral FTA negotiations not with standing the fact that the Trilateral Summit Meeting was reopened in Seoul in 2015. Each state has distinct views about the trilateral FTA. China's strategy is to hedge against U.S. influence in East Asia, while Japan's strategy is to participate in TPP in order to generate a soft balancing power against China through closer political linkages with the U.S.in the region. Korea's strategy is to maximize its economic interest in the region by participating in trilateral and mega FTAs [Lee, 2015; Yoshimatsu, 2014]. 


\section{Mega FTAs and Northeast Asian Cooperation}

\section{Background}

Asia's economies have been increasingly vital to each other and to the world. In 2013, Asia's economic output was roughly equal to that of Europe and North America. By 2020, it will be $50 \%$ larger in terms of purchasing power parity (PPP). Additionally, two major economies - the U.S. and the EU - are recovering from the global financial crisis relatively slowly with 1-2.5\% economic growth per annum, while Asian emerging economies such as China and India are growing at around 7\% per year. As a result, the centre of recovery for the global economy has decisively shifted from Europe and North America to Asia. Based on these factors, two different approaches to trade liberalization became clear in the Asia and Pacific Region. The first is the ASEAN-led (or de facto China-led) RCEP and the other is the U.S.-led TPP. These approaches were discussed during the ASEAN summit in November 2012.

In fact, the reason for discussing these two mega FTAs in the ASEAN summit was that the Doha Development Agreement (DDA) was delayed at the multilateral level and the bilateral FTAs were able to generate marginal gains for private sectors in ASEAN states. Therefore, Asian countries started to be concerned that a small number of countries focused on FTAs such as RCEP and TPP could direct the trade liberalization process in the region. They regarded the mega FTAs as easily negotiated with the flexibility to suit their domestic interests. The two mega FTAs have relatively similar objectives of trade liberalization and economic integration. At the same time, however, there are substantial differences [Basu Das, 2013].

The two mega FTAs have been widely recognized as representing a struggle between the U.S. and China to expand their economic and political influence in the Asia Pacific region. Both the RCEP and TPP could help reinvigorate the recently sluggish Asia Pacific economy in general and the Northeast Asian economy in particular by further promoting trade liberalization and economic integration. Such trends for further robust international trade and investment as well as strengthening the multilateral trading system have been endorsed by the G20 Summit in Hangzhou, China [www.g20. org, 2016].

\section{Regional Comprehensive Economic Partnership (RCEP)}

After several years of discussions about the desirability and feasibility of Asian economic cooperation, East Asian countries led by ASEAN members decided to establish the RCEP. States participating in the RCEP negotiations are the ten ASEAN members plus as Korea, China, Japan, India, Australia and New Zealand. Negotiations began in 2013.

Unlike Europe or the U.S., East Asia has not established a region-wide FTA due to different opinions among East Asian economies about what that might mean and as 
a result the process of securing agreement to the RCEP was drawn out. Regional economic cooperation in East Asia began to intensify in response to the Asian financial crisis in 1997 as the first ASEAN+3 (Korea, China and Japan) summit meeting was held in 1998. At the summit, Korea proposed to establish the East Asia Vision Group to overcome collective economic and financial problems in the region. The expert group further developed the idea of an East Asia Free Trade Area (EAFTA) in 2009 [Urata, 2013; EAFTA, 2009].

Parallel to the ASEAN+3 approach, at the ASEAN+6 economic ministers' meeting in 2006 Japan proposed the Comprehensive Economic Partnership in East Asia (CEPEA) which would form a region-wide FTA of ASEAN+6 members. These 16 states are the same members of the East Asia Summit that began in 2005. Japan was motivated to take a leadership role in setting up a regional institution in the context of its competition with China, which had taken the initiative in the EAFTA discussions. Thus, China's actions sped up the process of regional economic integration in East Asia. The Chinese motivation to establish a region-wide FTA was stronger than any other states in the region because it observed increasing U.S. influence in the push to form a regional economic framework in the Asia Pacific region under the TPP. In response, ASEAN proposed the RCEP involving ASEAN and its FTA partners in 2011 to avoid a loss of ASEAN centrality in East Asian regional integration. Furthermore, ASEAN announced the guiding principles for the negotiations of the RCEP would include WTO consistency, transparency and open accession for ASEAN's FTA partners and others. As a result, ASEAN+6 leaders agreed to launch the negotiation of RCEP in 2012 and to start in 2013. RCEP was scheduled to conclude by the end of 2015, but did not meet this target [ASEAN Secretariat, 2012; Urata, 2013].

The RCEP is a strong rival of the TPP in the context of East Asian economic integration. It captures a population of more than 3.4 billion people, with an economic output about $\$ 21$ trillion accounting for around $35 \%$ of world trade in 2014 . There is no doubt that RCEP could create the world's largest trading bloc if it is successfully concluded. It could have major implications for the global economy regarding the spread of global production networks, the reduction of the inefficiencies of multiple Asian FTAs, etc. [IMF, 2014; Suh, 2014] (Fig. 8).

To successfully conclude negotiations, the RCEP needs strong leadership from ASEAN, which is regarded as impartial. The role of ASEAN is also critical because China and Japan do not trust each other due to their rivalry in the region. RCEP is a tool for China to rise in the region, and ASEAN, Korea and Japan are concerned that China will eventually dominate East Asia through a China-led East Asia Economic Community. Therefore, some countries such as Japan, Myanmar, the Philippines and Vietnam have actively tried to balance between China and the U.S. in order to hedge against China's possible threat. For this reason, an RCEP based on ASEAN centrality can play a role in checking the rise of China and balancing power in the region [Suh, 2014]. 


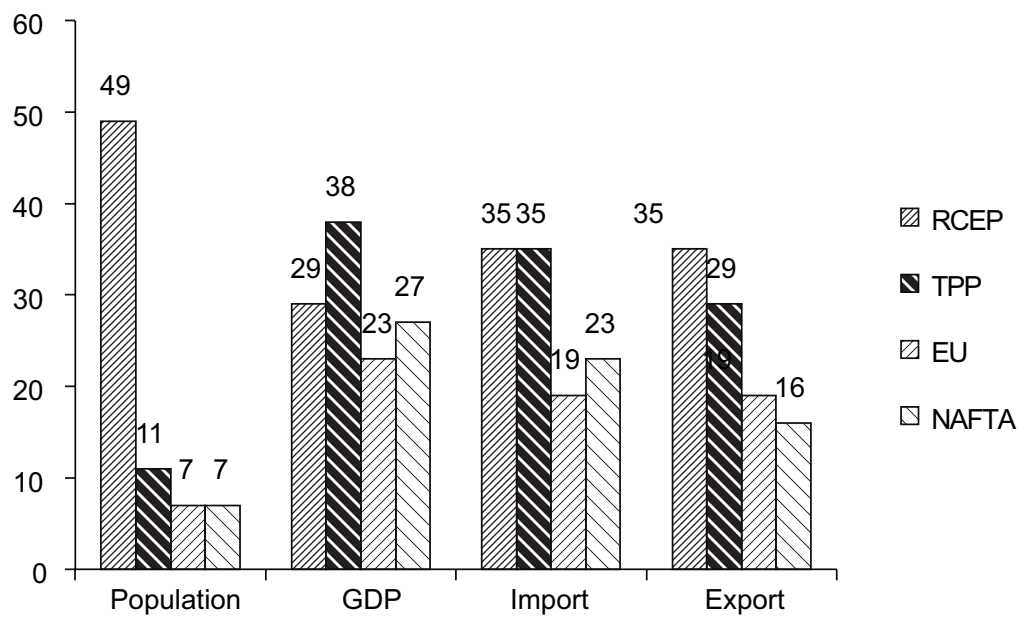

Fig. 8: RCEP's Share of World in Population, GDP and Trade (as of 2014, \%)

Source: [International Monetary Fund, 2014].

The trilateral FTA may accelerate the successful conclusion of the RCEP negotiations. Korea can play an important role in stepping up the agreement. The China - Korea FTA could be a useful model for the Korea - China - Japan FTA. Japan signed the TPP in 2015 after agreeing to open its agricultural sector, so Japan may have more room to negotiate the trilateral FTA than before if political and security issues are ruled out.

For Korea, concluding the RCEP means a de facto conclusion of the Korea China - Japan FTA because these three states participate in RCEP negotiations as well. In terms of trade and exports, the trilateral FTA is equal to the TPP. Therefore, Korea can play a role as an arbitrator in accelerating the trilateral FTA for Northeast Asian economic cooperation and the RCEP for region-wide economic cooperation (Fig. 9).

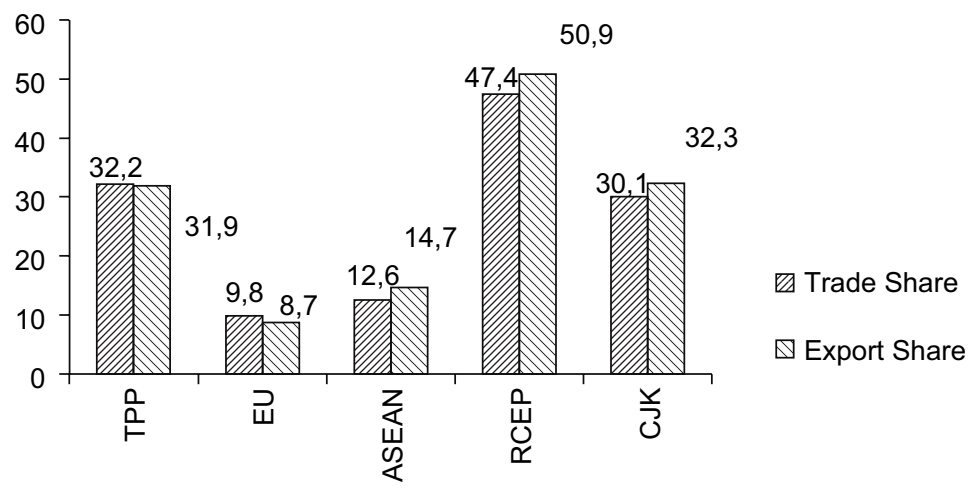

Fig. 9: Korea's Trade and Exports Share in Different Economic Blocs (as of 2014, \%)

Source: [Korea International Trade Association, 2015]. 
The TPP established a new global standard for international trade. With 29 chapters, 13 members set up new regimes for certain activities such as regulatory coherence, supply chain competitiveness and small- and medium-sized enterprises (SMEs) which had not been addressed in previous FTAs or the WTO until the TPP was signed in 2015. For this reason, the TPP is regarded as a $21^{\text {st }}$ century regional FTA.

The TPP may have the effect of isolating China in East Asia. The high standard of agreement within the TPP is a barrier for China to overcome in the near future. Although the TPP does not intend to marginalize China in East Asia, it is not currently possible for China to accept the content of TPP. It is inevitable that China will change its policies to sustain economic growth and ensure social stability. However, Chinese leadership understands that rapid market reform is not feasible and for this reason China cannot participate in TPP negotiations at least at present [Suh, 2014].

China should be concerned about Japanese participation in the TPP negotiations because it means that the U.S. has taken a step forward in isolating China in the region. In this situation, Korean participation in the TPP may not be desirable for China and could provoke a serious imbalance between the TPP and the RCEP. China could suffer from declining competitiveness if Korea joins the TPP negotiations in terms of its trade position based on economics and security. The impact could create instability in the region (Table 3).

China is the most important trade partner for Korea. Korean exports to China represent a quarter of the total export volume, with bilateral trade accounting for $\$ 229$ billion in 2013 and a Korean trade surplus of $\$ 62.8$ billion in the same year. These amounts increased to $\$ 235.4$ billion and $\$ 75.6$ billion respectively in 2014 . In addition, from a political point of view, China has significant influence on North Korea - a consideration directly related to the national security of South Korea [KITA, 2015; Suh, 2014].

Table 3: Comparison of GDP and Trade between TPP and RCEP (\$ Billion, \%)

\begin{tabular}{|l|c|c|c|c|}
\hline & TPP11 & TPP12 & TPP13 & RCEP \\
\hline \multirow{2}{*}{ GDP } & 22824 & 27831 & 29029 & 20983 \\
\cline { 2 - 5 } & 31,1 & 37,9 & 39,5 & 28,6 \\
\hline \multirow{2}{*}{ Trade } & 7858 & 9543 & 10610 & 13160 \\
\cline { 2 - 5 } & 21,2 & 25,8 & 28,7 & 35,5 \\
\hline
\end{tabular}

Source: [International Monetary Fund, 2014; World Trade Organization, 2016].

Note: TPP11: Japan is excluded, TPP12: TPP + Japan, TPP13: TPP12 + Korea.

Therefore, Korea as a middle power needs to pursue a balanced position in the Asia Pacific region not only for regional economic integration, but also for political stability. It would be wise for Korea to prepare for entrance into TPP negotiations and Korea had already expressed its interest in doing so prior to 2015, although the U.S. 
did not allow it. Korea has to guarantee that its participation in the TPP is not against China's national interests. The bilateral FTA between Korea and China, as well as Korea's effort in support of the RCEP negotiations, could create such a guarantee.

Korean TPP membership may be an expensive undertaking. Although the cost of membership itself is not a heavy burden, market access for goods must be taken into account. In its bilateral consultations with TPP partners, Korea may liberalize sensitive items such as rice and automobiles. The U.S. may push for a full liberalization of the Korean rice market, while Japan may demand immediate elimination of tariffs on Japanese car products. Korean TPP membership establishes a de facto bilateral FTA with Japan. Therefore, many Korean manufacturing companies are concerned that their products could be adversely affected by Japanese competition. Korea has experienced a serious and chronic trade deficit with Japan which increased from $\$ 11.4$ billion in 2000 to $\$ 36.1$ billion in 2010. Since then it has been reduced to $\$ 25.3$ billion in 2013 and $\$ 21.6$ billion in 2014 .

In sum, Korean TPP membership could generate some economic benefits such as greater bargaining power in ongoing negotiations with China and Japan for non-tariff barriers, consolidation of an alliance with the U.S. and rationalization of noodle bowl effects. However, the TPP has a limited ability to accelerate Northeast Asian economic integration because China cannot participate in the short term. Japan's use of the TPP as a soft balancing strategy against China also weakens China and Korea's willingness to engage in the trilateral FTA [Suh, 2014; Yoshimatsu, 2014].

\section{Conclusions}

The formation of the European single market in 1993 was an historically significant event with origins in the Rome Treaty of 1957. Twenty years later, an objective evaluation is very mixed although no one doubts that the single market has had a tremendous impact on the political, economic, cultural, social and security landscape of the EU. The single market has contributed to economic growth in the EU average 2.0-2.5\% last over 20 years.

Despite this economic growth, the euro crisis stemming from the sovereignty debt crisis fueled concerns of a global economic downturn and worries about the EU's future. Additionally, the most advanced model of regional economic integration began to appear as a cautionary example, particularly as East Asia was trying to advance its own economic integration.

Most East Asian countries completed their bilateral or multilateral FTAs in the 1990s although ASEAN was formed earlier. In fact, ASEAN has played a role in the development of East Asian economic integration with major East Asian countries such as Korea, China, Japan and India forming ASEAN+1, ASEAN+3 and ASEAN+6. The region's major economies - Korea, China and Japan - have realized the necessity of pursuing their own economic integration though the Northeast Asian Economic Community. After several years of study, trilateral FTA negotiations started after 2013. 
However, these face many obstacles due to various conflicts between the three states, including different national economic interests. As a result, the process is rather slow.

In parallel to trilateral FTA negotiations, mega FTAs such as the RCEP and the TPP have become urgent issues in the Asia Pacific for reasons related to regional economic integration and also political and security cooperation. The RCEP, led formally by ASEAN, but in a de facto manner by China, was to be completed by 2015 . However, this target date has to be pushed back to 2017. If completed, the RCEP could be one of the largest FTAs in the world with $29 \%$ of the global GDP. It would also be the most important trade bloc for the Korean economy due to the inclusion of its close trade partners among RCEP membership.

TPP negotiations were completed in 2015, but Korea missed its opportunity to participate. However, Korea will try to start negotiations along with Taiwan. Negotiation of the TPP is rather sensitive for Korea because it involves not only regional economic integration, but also political and security issues. Additionally, TPP membership for Korea means a de facto bilateral FTA with Japan. Therefore, Korea is still very cautious. Some scholars describe this as Korea's strategic dilemma [Kim and Cha, 2016]. However, it can also be an opportunity for Korea - Korea completed a bilateral FTA with China in 2015 and could complete a de facto FTA with Mexico after becoming a member of the TPP. As a result, Korea can catch two rabbits at once if it can overcome possible pressure on the issue of liberalization of rice from the U.S. and immediate elimination of tariffs from Japan.

\section{References}

ASEAN Secretariat (ASEAN) (2012). "Guiding Principles and Objectives for Negotiating the Regional Comprehensive Economic Partnership." Available at: http://dfat.gov.au/trade/agreements/rcep/documents/guiding-principles-rcep.pdf (accessed July 2017)

Asian Development Bank (ADB) (2014). Asian Economic Integration Report. Manila: ADB.

Basu Das, S. (2013). "RCEP and TPP: Comparisons and Concerns." ISEAS Perspective 2.

Chiang, M.H. (2013). "The Potential of China - Japan - South Korea Free Trade Agreement.” East Asia: An International Quarterly 30 (3), pp. 199-216.

China National Bureau Statistics (NBS) (2016). National Data, Annual National Accounts, Cross Domestic Product, Beijing: CNBS.

Choi, Y.M. (2013). “The Optimal Path of a China-Japan-Korea FTA: Multilateral Path or Sequential Path?” Pacific Focus 28 (3), pp. 435-458.

Copenhagen Economics (2012) Delivering a Stronger single market, Nordic Innovation Report 2012.

Corning, G.P. (2014). "CJK Investment Agreements in East Asia: Building a Bifurcated Investment Regime.” Asian Politics \& Policy 6 (2), pp. 285-306.

Dent, C.M. (2003). "Networking the Region? The Emergence and Impact of Asia Pacific Bilateral Free Trade Agreement Projects." The Pacific Review 16 (1), pp. 1-28.

Dicken, P. (2015). Global Shift (7 $7^{\text {th }}$ edition). London: The Guildford Press.

EAFTA (2009). Desirable and Feasible Option for an East Asia FTA, A Report by Joint Expert Group on EAFTA Phase II Study. 
European Commission (2012a). 20 Years of European single market - Together for New Growth. Luxembourg: EC.

European Commission (2012b). Council Regulation 2012/0242 (CNS). Brussels: EC.

Godement, F. (2013). Divided Asia: The Implications for Europe, European Council Foreign Relations (ECFR) 91. November.

Hiebert, M. and L. Hanlon (2013). "ASEAN and Partner: Regional Comprehensive Economic Partnership, Critical Question.” CSIS, 7 December.

Hong, G.H. and S.H. Oh (2013). "Gains from Trade Liberalization between Heterogeneous Countries: Implications for Korea-Japan FTA.” Working Paper 13-09, Seoul: KIEP.

Ilzkovitz, F., A. Dierx, V. Kovacs and N. Sousa (2007). "Steps towards a Deeper Economic Integration: The Internal Market in the 21st Century.” European Economy 271.

International Monetary Fund (IMF) (2014). World Economic Outlook Database, October. Washington DC: IMF.

International Monetary Fund (IMF) (2015) Direction of Trade Statistics. Washington DC: IMF.

Jin, H.J, W.W. Koo and B.S. Sul (2006). "The Effects of the Free Trade Agreement Among China, Japan and South Korea." Journal of Economic Development 31 (2), pp. 55-72.

Katzenstein, P. (1997). "Introduction: Asian Regionalism in Comparative Perspective.” In: P. Katzenstein and T. Shiraishi, eds., Network Power: Japan and Asia. Ithaca: Cornell University Press.

Katzenstein, P. (2005). A World of Regions: Asia and Europe in the American Imperium. Ithaca: Cornell University Press.

Kim, E. and V. Cha (2016). "Between a Rock and Hard Place: South Korea's Strategic Dilemmas with China and the United States." Asia Policy 21, January, pp. 101-121.

Kimura, F. and M. Ando (2008). “Economic Obstacles to a Northeast Asian FTA.” In: J. Park, T.J. Pempel and G. Roland, eds., Political Economy of Northeast Asian Regionalism: Political Conflict and Economic Integration. Cheltenham and Northampton: Edward Elgar.

Kirton, J. (2013). G20 Governance for a Globalized World. Farnham: Ashgate.

Korea International Trade Association (KITA) (2014). "Investment in China in the First Half of This Year: Inversion of Korea and Japan in 7 Years.” 28 August.

Korea International Trade Association (KITA) (2015). "Trade Statistics.” Available at: http://www.kita net (accessed July 2017).

Kox, H. (2005). "Intra EU Differences in Regulation Caused Administrative Burden for Companies." CPB Memorandum. The Hague: CPB.

Lee, C.J. (2015). “A Northeast Asian Economic Community: A Korean Perspective.” In: L.J. Cho and C.J. Lee, eds., Building a Northeast Asian Economic Community. Sejong City: KISTEP.

Looney, R. (2014). Handbook of Emerging Economies. New York: Routledge.

Madhur, S. (2013). "China-Japan-Korea FTA: A Dual Track Approach to a Trilateral Agreement.” Journal of Economic Integration 28 (3), pp. 375-392.

Mayer, T. and G. Ottaviano (2007). The Happy Few, the Internationalization of European Firms. Brussels/ London: Bruegel Blueprint Series and CEPR.

Pelkmans, J. (2012). "The Economics of Single Market Regulation.” Bruges European Economic Policy Briefings 25.

Pempel, T.J. (2010). "Soft Balancing, Hedging and Institutional Darwinism: The Economic Security Nexus and East Asian Regionalism.” Journal of East Asian Studies 10, pp. 209-238.

Pempel, T.J. (2013). "Regional Institutions and the Economy-Security Nexus." In: T.J. Pemple, ed., The Economy Security Nexus in Northeast Asia. London: Routledge, pp. 146-163. 
Schott, J. J., E. J. Jung and C. Cimino-Isaacs (2015). "An Assessment of Korea-China Free Trade Agreement.” Policy Brief PB15-24, Washington DC: Peterson Institute for International Economics.

Schott, J. J. and C. Cimino-Isaacs (2015). "The China-Japan-Korea Trilateral Investment Agreement: Implications for US Policy and US-China Bilateral Investment Treaty." In: "Towards US-China Investment Treaty." PIIE Briefing 15-1.

Song, S. (2013). "China, Japan and South Korea Begin FTA Talks.” Global Times. 27 March.

Straathof, B., G. J. Linders, A. Lejour and J. Mohlmann (2008). "The Internal Market and the Dutch Economy: Implications for Trade and Economic Growth." CPB Netherlands Bureau for Economic Policy Analysis Amsterdam: CPB Netherlands Bureau.

Suh, J. K. (2014). "Korean Bridge: Balancing Asian Economic Regionalism between the United States and China." In: G. Rozman, ed., Joint US-Korea Academic Studies 25, Washington D. C.: Korea Economic Institute of America.

Szczudlik-Tatar, J. (2013). “China's New Silk Road Diplomacy.” The Polish Institute of International Affairs (PISM) 34 (82), pp. 1-8.

Urata, S. (2013). "Constructing and Multilateralizing the Regional Comprehensive Economic Partnership: An Asian Perspective." ADBI Working Paper Series 449, Tokyo: ADBI.

Vetter, S. (2013). “The Single European Market 20 Years On.” EU Monitor. October. Deutsche Bank DB Research.

World Trade Organization (WTO) (2016). "Trade Statistics and Outlook.” Press 768, 7 April. Available at: https://www.wto.org/english/news_e/pres16_e/pr768_e.pdf accessed on 07 (accessed October 2016).

Yoshimatsu, H. (2014). "Trade Politics in Northeast Asia: The Development of the Trilateral Free Trade Agreement.” RCAPS Working Paper RWP-14001.

Zhao, S. (1998). "Soft versus Structural Regionalism: Organizational Forms of Cooperation in Asia Pacific." The Journal of East Asian Affairs 12 (1), pp. 96-134. 
Может ли торговля способствовать

преодолению экономического кризиса?

Опыт Республики Корея, Китая и Японии по формированию

региональных соглашений о свободной торговле (ССТ), мегаССТ (Всеобъемлющее региональное экономическое партнерство (ВРЭП) и Транстихоокеанское партнерство $(\mathrm{TТП)})^{1}$

\author{
С.- - П. Пак
}

Пак Санг-Чул - профессор Высшей школы наукоемких технологий и энергетики, Политехнический университет Республики Корея; 2121 Jeongwang-Dong, Siheung-City, Kyonggi-Do, 429-793, Korea; E-mail: scpark@kpu.ac.kr.

Благодаря процессам глобализации начиная с 1990-х годов в мире оформились три крупнейших с точки зрения ВВП и объемов торговли торгово-экономических блока: Европейский союз, Североамериканская зона свободной торговли (НАФТА) и страны Северо-Восточной Азии, которые стали играть определяюшую роль в глобальной торгово-экономической системе.

Однако глобальный финансовый кризис 2008 г. привел к изменениям глобального экономического порядка и системы управления. Центры влияния переместились в такие блоки, как «Группа семи», а также включающие страны с развивающейся рыночной экономикой «Группу двадиати» и БРИКС. В условиях глобальных экономических изменений глобальная торговля способствовала быстрому росту мировой экономики на протяжении последних пяти десятилетий. В сфере заключения соглашений о свободной торговле (CCT) Европейский союз (ЕC) является лидером. ЕС удалось создать наиболее развитую систему региональной экономической интеграции. Единый рынок ЕС стал примером для ряда стран Северо-Восточной Азии, ведущих переговоры о заключении региональных и многосторонних соглашений о свободной торговле, а также участвующих в различных мегаССТ, таких как ВРЭП и ТТП. В результате противоречия в сфере политики и безопасности в регионе Северо-Восточной Азии привели к более серьезному расхождению экономических интересов. Вследствие этого странам Северо-Восточной Азии сложнее выстраивать свою экономическую интеграцию в точном соответствии с примером ЕС.

В статье рассматриваются возможные региональные ССТ между Республикой Корея, Китаем и Японией, которые могут стать основой для процессов региональной экономической интеграции, а также создать удобную платформу для укрепления торговли и дальнейшего стимулирования экономического роста. В статье также рассматриваются экономические интересы трех указанных стран относительно участия в мегаССТ, таких как ВРЭП и ТТП. Автор исследует лучший сиенарий участия в многосторонних ССТ и мегаССТ для каждой страны.

Ключевые слова: единый рынок; региональная экономическая интеграция; соглашение о свободной торговле (ССТ); мегаССТ; экономический рост; стратегия в отношении заключения ССТ

Для цитирования: Пак С.-Ч. Может ли торговля способствовать преодолению экономического кризиса? // Вестник международных организаций. 2017. T. 12. № 2. C. 104-128. DOI: 10.17323/1996-7845-2017-02-104

${ }^{1}$ Работа выполнена при поддержке Национального исследовательского фонда при Правительстве Республики Корея (NRF 2015S1A3A2046684).

Статья поступила в редакцию в ноябре 2016 г. 


\section{Литература}

ASEAN Secretariat (ASEAN) (2012) Guiding Principles and Objectives for Negotiating the Regional Comprehensive Economic Partnership. Режим доступа: http://www.asean.org/asean/asean-summit/item/asean-framework-forregionalcomprehensive-economic-partnership (дата обращения: 07.04.2017).

Asian Development Bank (ADB) (2014) Asian Economic Integration Report 2014. Manila: ADB.

Basu Das S. (2013) RCEP and TPP: Comparisons and Concerns // ISEAS Perspective. No. 2. 17 August. Chiang M.-H. (2013) The Potential of China-Japan-South Korea Free Trade Agreement // East Asia: An International Quarterly. Vol. 30. No. 3. P. 199-216.

China National Bureau Statistics (2016) National Data, Annual National Accounts, Cross Domestic Product. Beijing: CNBS.

Choi Y.-M.(2013) The Optimal Path of a China - Japan - Korea FTA: Multilateral Path or Sequential Path? // Pacific Focus. Vol. 28. No. 3. P. 435-458.

Copenhagen Economics (2012) Delivering a Stronger Single Market. Nordic Innovation Report 2012. P. 12. Corning G.P. (2014) CJK Investment Agreements in East Asia: Building a Bifurcated Investment Regime // Asian Politics \& Policy. Vol. 6. No. 2. P. 285-306.

Dent C.-M. (2003) Networking the Region? The Emergence and Impact of Asia Pacific Bilateral Free Trade Agreement Projects // The Pacific Review. Vol. 16. No. 1. P. 1-28.

Dicken P. (2015) Global Shift, $7^{\text {th }}$ ed. London: The Guildford Press.

EAFTA (2009) Desirable and Feasible Option for an East Asia FTA. A Report by Joint Expert Group on EAFTA Phase II Study.

European Commission (2012a) 20 Years of European Single Market - Together for New Growth. Luxembourg: EC.

European Commission (2012b) Council Regulation, 2012/0242 (CNS). Brussels: EC.

Godement F. (2013) Divided Asia: The Implications for Europe, European Council Foreign Relations (ECFR)/91, November.

Hiebert M., Hanlon L. (2013) ASEAN and Partner: Regional Comprehensive Economic Partnership // Critical Question, CSIS, 7 December.

Hong G.-H., Oh S.-H. (2013) Gains from Trade Liberalization between Heterogeneous Countries: Implications for Korea-Japan FTA. Working Paper 13-09. Seoul: KIEP.

Ilzkovitz F., Dierr A., Kovacs V., Sousa N. (2007) Steps towards a Deeper Economic Integration: the Internal Market in the 21st Century. A Contribution to the Single Market Review // European Economy. No. 271 (January). Brussels: European Commission.

International Monetary Fund (2014) World Economic Outlook Database, October. Washington D. C. International Monetary Fund (IMF) (2015) Direction of Trade Statistics. Washington D. C.

Jin H.-J., Koo W.-W., Sul B.-S. (2006) The Effects of the Free Trade Agreement among China, Japan and South Korea // Journal of Economic Development. Vol. 31. No. 2. P. 55-72.

Katzenstein P. (1997) Introduction: Asian Regionalism in Comparative Perspective // Network Power: Japan and Asia / Katzenstein P., Shiraishi T. (eds). Ithaca: Cornell University Press.

Katzenstein P. (2005) A World of Regions: Asia and Europe in the American Imperium. Ithaca: Cornell University Press.

Kim E., Cha V. (2016) Between a Rock and Hard Place: South Korea's Strategic Dilemmas with China and the United States // Asia Policy. No. 21 (January). P. 101-121.

Kimura F., Ando M. (2008) Economic Obstacles to a Northeast Asian FTA // Political Economy of Northeast Asian Regionalism: Political Conflict and Economic Integration / J. Park, T.J. Pempel, G. Roland (eds). Cheltenham and Northampton: Edward Elgar. 
Kirton J. (2013) G20 Governance for a Globalized World. Farnham: Ashgate.

Korea International Trade Association (KITA) (2014) Investment in China in the First Half of This Year, Inversion of Korea and Japan in 7 Years, 28 August.

Korea International Trade Association (KITA) (2015) Trade Statistics. Режим доступа: www.kita.net (дата обращения: 07.04.2017).

Kox H. (2005) Intra EU Differences in Regulation caused Administrative Burden for Companies. CPB Memorandum. The Hague: CPB.

Lee C.-J. (2015) A Northeast Asian Economic Community: A Korean Perspective // Building a Northeast Asian Economic Community / L.-J. Cho, C.-J. Lee (eds). Sejong City: KISTEP. P. 25-38.

Looney R. (2014) Handbook of Emerging Economies. New York: Routledge.

Madhur S. (2013) China-Japan-Korea FTA: A Dual Track Approach to a Trilateral Agreement // Journal of Economic Integration. Vol. 28. No. 3. P. 375-392.

Mayer T., Ottaviano G. (2007) The Happy Few: The Internationalization of European Firms. BruegelCEPR EFIM 2007 Report. Bruegel Blueprint Series and CEPR.

Pelkmans J. (2012) The Economics of Single Market Regulation. Bruges European Economic Policy Briefings, 25/2012.

Pempel T.J. (2010) Soft Balancing, Hedging, and Institutional Darwinism: The Economic Security Nexus and East Asian Regionalism // Journal of East Asian Studies. Vol. 10. P. 209-238.

Pempel T.J. (2013) Regional Institutions and the Economy-Security Nexus // The Economy Security Nexus in Northeast Asia / T.J. Pempel (ed.). P. 146-163. L.: Routledge.

Schott J.J., Cimino-Isaacs C. (2015) The China-Japan-Korea Trilateral Investment Agreement: Implications for US Policy and US-China Bilateral Investment Treaty // Towards US-China Investment Treaty, PIIE Briefing 15-1.

Schott J.J., Jung E.J., Cimino-Isaacs C. (2015) An Assessment of Korea-China Free Trade Agreement. Policy Brief, PB15-24.Washington D.C.: Peterson Institute for International Economics.

Song S. (2013) China, Japan and South Korea begin FTA Talks // Global Times. 27 March.

Straathof B., Linders G.J., Lejour A., Mohlmann J. (2008) The Internal Market and the Dutch Economy: Implications for Trade and Economic Growth. CPB Netherlands Bureau for Economic Policy Analysis. Amsterdam: CPB Netherlands Bureau.

Suh J.K. (2014) Korean Bridge: Balancing Asian Economic Regionalism between the United States and China // Joint US-Korea Academic Studies / G. Rozman (ed.). Washington D. C.: Korea Economic Institute of America. Vol. 25. P. 188-199.

Szczudlik-Tatar J. (2013) China's New Silk Road Diplomacy // The Polish Institute of International Affairs Policy Paper. Vol. 34. No. 82. P. 1-8.

Urata S. (2013) Constructing and Multilateralizing the Regional Comprehensive Economic Partnership: An Asian Perspective. ADBI Working Paper Series. No. 449. Tokyo: ADBI.

Vetter S. (2013) The Single European Market 20 years on // EU Monitor, October, Deutsche Bank Research. Режим доступа: http://www.dbresearch.com/PROD/DBR_INTERNET_EN-PROD/ PROD000000000 322897.pdf (дата обращения: 07.04.2017).

World trade Organization (WTO) (2016) Trade Statistics and Outlook, Press 768, 7 April. Режим доступа: https://www.wto.org/english/news_e/pres16_e/pr768_e.pdfaccessedon 07 (дата обращения: 07.04.2017).

Yoshimatsu H. (2014) Trade Politics in Northeast Asia: The Development of the Trilateral Free Trade Agreement. RCAPS working Paper, RWP-14001.

Zhao S. (1998) Soft Versus Structural Regionalism: Organizational Forms of Cooperation in Asia Pacific // The Journal of East Asian Affairs. Vol. 12. No. 1. P. 96-134. 